\title{
Mechanisms of knowledge-driven innovation: evidence from Russia
}

\author{
Mariia Molodchik ${ }^{1, *}$, Anatoliy Molodchik ${ }^{2}$, and Irena Esaulova ${ }^{2}$ \\ ${ }^{1}$ National Research University HSE, Perm campus, 38, Studencheskay str., Perm, 614070, Russia \\ ${ }^{2}$ Perm National Research Polytechnic University, 29, Komsomolsky pr., Perm, 614990, Russia
}

\begin{abstract}
The paper aims to propose theoretical framework for knowledge-driven innovation and justify it empirically using database of 110 Russian companies. The study utilizes multidisciplinary approach and develops theoretical framework in the intersection of knowledge-based theory of a firm, the concept of learning organization, the concept of intellectual capital and the concept of self-development and selforganizational systems. The partial least square was applied for modelling the impact of the flexible structure, knowledge culture, transformational leadership on proactive employee behavior that in turn influences knowledge resources and organizational learning followed by company's innovation. The study confirmed the key role of proactive behavior in knowledge-driven innovation. Findings revealed the highest impact of transformational leadership on employee behavior and innovation, as well as positive and significant impact of knowledge culture and indirect effect of flexible structure.
\end{abstract}

\section{Introduction}

Innovation activities are one of the main sources of company success and sustainable development $[1,2]$. Consequently, the search for innovation drivers attracts scholars' attention and has wide practical implications for business. For Russian business context such research is of particular importance because Russia has a catching up position in innovation activities. Namely, the level of innovation activities in 2019 in Russia was equal 9,1; while in developed countries it is higher than 60 points. Another example of innovation gap is the share of innovation products in sales, which was 5,3\% in 2019 for Russian companies [3].

Knowledge-driven innovation is an emerging topic and allows at investigating sources of innovations that are connected with knowledge management. Most theoretical and empirical studies discussed the question of knowledge impact on innovation performance [2, 4], meanwhile the question of mechanisms, which intensify knowledge resources and push the processes of organizational learning, is still underdeveloped.

This study aims to propose a novel theoretical framework for knowledge-driven innovation of a company. It will contribute to innovation and knowledge management field with discovering mechanisms of knowledge transformation into innovation. The rest of the paper is organized as follows. Next section is devoted to theoretical background. Further the authors describe the methodology of the study. Results and conclusions finalize the paper.

\section{Theoretical background}

The theoretical framework for knowledge-driven innovation is elaborated in the intersection of the following theories: knowledge-based theory developed by Grant [5], organizational learning concept proposed by Argiris and Shon [6], intellectual capital concept developed by Stewart [7] and concept of selfdevelopment and self-organizational systems proposed by Molodchik et al. [8].

According to Oslo Manual an innovation is "a new or improved product or process (or combination thereof) that differs significantly from the unit's previous products or processes and that has been made available to potential users (product) or brought into use by the unit (process)" [9]. Scholars confirmed that knowledge resources are a base for innovation, but what mechanism states behind this link is still a black box and call for detailed investigation. Knowledge resources contain human, organizational, innovation and relational resources according to the concept of intellectual capital [7]. These resources are organized and managed within the processes of organizational learning. According to Garvin et al. [10] organizational learning is a spiral mechanism of creating and sharing knowledge among individuals, groups, and the entire organization. Concrete learning processes include experimentations, information collection and transfer, analysis, education and training.

The authors of this study suppose that organizational learning mediates the impact of knowledge endowment on innovation. Therefore, the first proposition of this study is as follows, the organizational learning has positive impact on company's innovation. 
The second question addressed in the study concerns the drivers of organizational learning and knowledge resources. One of the answers might be a vector of employee proactive behavior. The concept of proactive behavior was introduced in early $90^{\text {th }}$ by Crant [11] and further developed by Parker et al. [12]. The proactive behavior includes the patterns of self-development, initiative and organizational commitment. Taking into account this concept the authors put forward the second proposition of the study: employees with proactive behavior intensify knowledge resources and participate in organizational learning processes. Altogether, proactive behavior, organizational learning and knowledge resources constitute knowledge capability of a company to drive its innovation.

Searching deeper in understanding the knowledgedriven innovation, the authors propose mechanisms that activate such proactive behavior. These organizational and motivational mechanisms include knowledge culture, transformational leadership and flexible structure. Knowledge culture is a specific type of culture that encourages knowledge creation, knowledge sharing, and knowledge application [10]. Transformational leadership is based on encouraging employees to accomplish extraordinary tasks [13]. Some studies found out that transformational leadership might facilitate individual learning and employee engagement. At the same time leadership is acknowledged as a shaping factor of the knowledge culture. Flexible structure determines the level of autonomy and decentralization within the company. According to [14] organizational structure is an antecedent for many KM practices and therefore, affects KM output. Meanwhile, organizational structure is the most understudied issue in KM topic. Third proposition of this study states that organizational and motivational mechanisms induce proactive employee behavior, which in turn intensifies knowledge resources and activates organizational learning.

Summarizing all propositions stated above the theoretical framework of knowledge-driven innovation chain can be elaborated (fig.1).

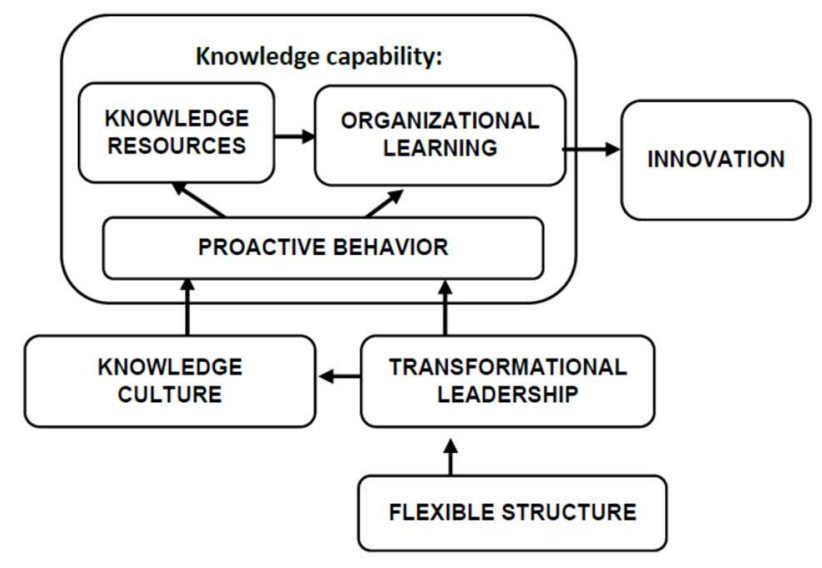

Fig. 1. Theoretical framework "Mechanisms of knowledgedriven innovation".

Elaborated theoretical framework considers flexible organizational structure as exogenous variable which is the premise for the chain of knowledge-driven innovation. Meanwhile, transformational leadership and knowledge culture have direct impact on proactive behavior. Moreover, following the study of Molodchik and Jardon [14] this framework proposes that transformational leadership has an impact on knowledge culture. To the best of our knowledge the presented framework is the first one giving the complex view on knowledge-driven innovation specifically for Russian business context.

\section{Methodology and database}

In order to justify empirically the elaborated theoretical framework, the authors performed quantitative study on the sample of 110 Russian companies. The importance of knowledge management and innovation promotion in Russian business context was underlined in several studies $[15,16]$. The database was collected in 20192020 using google form shared with the help of "snowball" technique and questions with regard to company's innovation, knowledge resources, organizational learning, proactive behavior, knowledge culture, transformational leadership and organizational structure. The questionnaire contained statements with 5point Likert scale answers. Table 1 represents metrics with loadings and latent variables of the study.

The companies are from different industries but mostly from manufacturing one, in particular $64 \%$ of the sample. $51 \%$ from the sample have R\&D expenditures, and $21 \%$ has high technological level compared with foreign competitors, $48,5 \%$ of companies are certified according ISO. On average around $70 \%$ of employees have high education degree, at the same time only $43 \%$ upgraded their qualification during last year. Relational resources were estimated through long-term agreements, collaboration with educational institutions and export activities. According to the survey $47 \%$ of companies excel export activities, more than $60 \%$ have relationships with universities and other educational institutions, 53\% have long-term agreements with customers. These indicators were used to estimate the endowment of knowledge resources. The index of knowledge resources was calculated using principal component analysis.

In order to estimate innovation activities, the respondents were asked about product, technological, marketing and management innovations in a company, whether they were increased or not during last three years. 5-point Likert scale was also applied to these questions.

For econometric methodology the authors used partial least square technique with the help of software smartPLS [17]. This method fits for exploratory studies, can be used for small samples and allows at investigating complex structural paths of the model. In particular, the authors implemented mediation analysis, in which an antecedent variable affects a mediating variable, which then affects a dependent variable. Therefore, a researcher can explain the process or mechanism by which one variable affects another. 
Table 1. Loadings of latent variables

\begin{tabular}{|c|c|}
\hline Metrics & Loadings \\
\hline \multicolumn{2}{|c|}{$\begin{array}{l}\text { Organizational learning }(\mathrm{CA}=0,80 ; \mathrm{CR}=0,86 \\
\mathrm{AVE}=0,56)\end{array}$} \\
\hline $\begin{array}{l}\text { Organization attracts, develops and retain } \\
\text { talented employees }\end{array}$ & 0,707 \\
\hline $\begin{array}{l}\text { Organization experiments frequently, } \\
\text { initiates new product development }\end{array}$ & 0,765 \\
\hline $\begin{array}{l}\text { Positive experience of one department is } \\
\text { spread over the whole organization fast }\end{array}$ & 0,717 \\
\hline $\begin{array}{l}\text { Organization regularly conducts monitoring } \\
\text { and compare itself with competitors and } \\
\text { best practices of leading companies }\end{array}$ & 0,757 \\
\hline $\begin{array}{l}\text { Organization initiates joint projects with } \\
\text { potential partners }\end{array}$ & 0,794 \\
\hline \multicolumn{2}{|c|}{ Proactive behavior $(\mathrm{CA}=0,85 ; \mathrm{CR}=0,89 ; \mathrm{AVE}=0,57)$} \\
\hline $\begin{array}{l}\text { Most employees are able to achieve the } \\
\text { desired results with minimal control from } \\
\text { the management }\end{array}$ & 0,735 \\
\hline $\begin{array}{l}\text { Employees are ready to upgrade their } \\
\text { professional qualification during private } \\
\text { time }\end{array}$ & 0,831 \\
\hline $\begin{array}{l}\text { Employees introduce initiatives on new } \\
\text { product and services development }\end{array}$ & 0,766 \\
\hline $\begin{array}{l}\text { Employees experiment and initiate new } \\
\text { ways of working with customers }\end{array}$ & 0,808 \\
\hline $\begin{array}{l}\text { Employees are ready to work for a long } \\
\text { time in the enterprise }\end{array}$ & 0,631 \\
\hline $\begin{array}{l}\text { Employees voluntarily, even detriment } \\
\text { personal interests, make additional efforts to } \\
\text { achieve the desired results }\end{array}$ & 0,760 \\
\hline \multicolumn{2}{|c|}{ Knowledge culture $(\mathrm{CA}=0,89 ; \mathrm{CR}=0,92 ; \mathrm{AVE}=0,70)$} \\
\hline $\begin{array}{l}\text { Organization encourages strive for } \\
\text { education }\end{array}$ & 0,826 \\
\hline $\begin{array}{l}\text { Organization encourages, values and } \\
\text { rewards team work }\end{array}$ & 0,875 \\
\hline $\begin{array}{l}\text { Organization encourages their employees } \\
\text { for initiative behavior, to elaborate new } \\
\text { ideas for product, process and technological } \\
\text { development }\end{array}$ & 0,824 \\
\hline $\begin{array}{l}\text { Organization encourages employees to } \\
\text { define the task and to achieve the goals with } \\
\text { high level of independency }\end{array}$ & 0,870 \\
\hline $\begin{array}{l}\text { There is a high level of trust between people } \\
\text { in the company }\end{array}$ & 0,782 \\
\hline \multicolumn{2}{|c|}{$\begin{array}{l}\text { Transformational leadership }(\mathrm{CA}=0,85 ; \mathrm{CR}=0,89 ; \\
\mathrm{AVE}=0,69)\end{array}$} \\
\hline $\begin{array}{l}\text { Leaders inspire others to solve complex } \\
\text { problems and to accomplish extraordinary } \\
\text { results }\end{array}$ & 0,793 \\
\hline $\begin{array}{l}\text { Leaders take into account the opinion of } \\
\text { other employees }\end{array}$ & 0,821 \\
\hline $\begin{array}{l}\text { Leaders delegate authority and decision- } \\
\text { making for achieving strategic purposes of a } \\
\text { company }\end{array}$ & 0,834 \\
\hline $\begin{array}{l}\text { Leaders are examples of entrepreneurial, } \\
\text { responsible, innovative behaviour }\end{array}$ & 0,867 \\
\hline
\end{tabular}

\begin{tabular}{|l|c|}
\hline $\begin{array}{l}\text { Organizational structure allows leadership } \\
\text { behavior at all levels }\end{array}$ & 0,876 \\
\hline $\begin{array}{l}\text { Organizational structure allows one to } \\
\text { create new structural units in short time } \\
\text { period }\end{array}$ & 0,877 \\
\hline $\begin{array}{l}\text { Organizational structure allows one to } \\
\text { delegate authority to employee, which } \\
\text { decided to take responsibility for new } \\
\text { project }\end{array}$ & 0,883 \\
\hline
\end{tabular}

\section{Results}

The model estimated in smartPLS package fits all indicators of reliability and validity. In table 1 one can see the values of Cronbach alpha (CA), complex reliability (CR) and average value extracted (AVE). The standardized root mean square residual of estimated model is SRMR=0.082, which reflects appropriate level for model acceptance. Exploratory power expressed with $\mathrm{R}^{2}$ was higher than $15 \%$ for all dependent variables, that also reflects appropriate level for model acceptance. Moreover, the dependent variables "proactive behavior" and "innovation" demonstrated $\mathrm{R}^{2}$ higher than $50 \%$ (see table 2). The significance of structural paths was estimated with the help of bootstrapping at alpha level equals 0,05 . Figure 2 presents direct paths of estimated model.

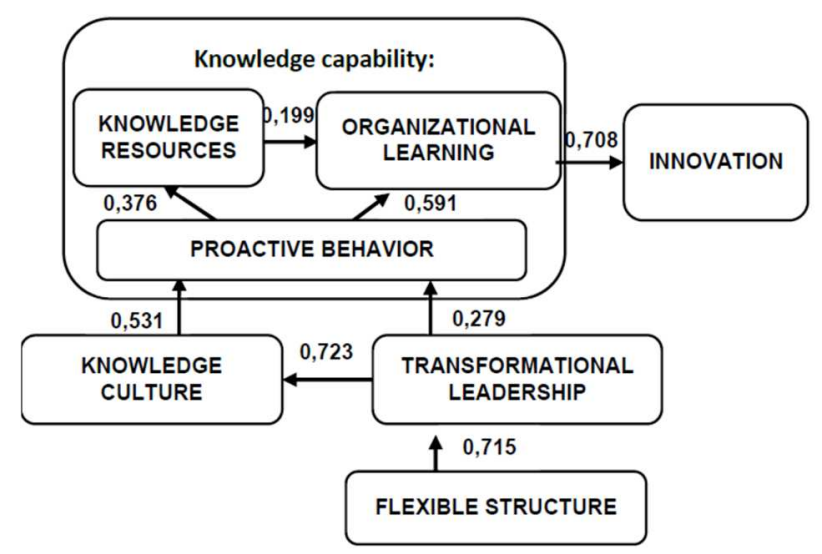

Fig. 2. Empirical results.

According to PLS modelling all three propositions put forward in the study were confirmed by empirical testing. Path modelling with bootstrapping procedure allowed to reveal all mediation effects and to estimate total effects of knowledge capability and organizational and motivational mechanisms on company's innovation. The study revealed full mediation effect of organizational learning on the link between proactive behavior and company's innovation. This empirical evidence underlines that for Russian companies organizational learning is a crucial capability for innovation performance.

Table 2 presents the final results of the study with regard to total effects of the model. 
Table 2. Total effects of the model

\begin{tabular}{|c|c|c|c|}
\hline & $\begin{array}{l}\text { Element of the } \\
\text { model }\end{array}$ & $\begin{array}{c}\text { Proactive } \\
\text { behavior } \\
\mathrm{R}^{2}=58,3 \%\end{array}$ & $\begin{array}{l}\text { Innovation } \\
\mathrm{R}^{2}=50,1 \%\end{array}$ \\
\hline \multirow{3}{*}{ 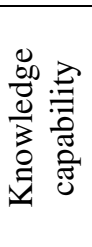 } & $\begin{array}{l}\text { Organizational } \\
\text { learning }\end{array}$ & & 0,708 \\
\hline & $\begin{array}{c}\text { Knowledge } \\
\text { resources }\end{array}$ & & 0,140 \\
\hline & $\begin{array}{l}\text { Proactive } \\
\text { Behavior }\end{array}$ & & 0,472 \\
\hline \multirow{3}{*}{ 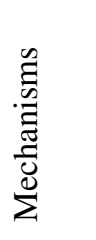 } & $\begin{array}{c}\text { Knowledge } \\
\text { Culture }\end{array}$ & 0,531 & 0,250 \\
\hline & $\begin{array}{c}\text { Transformational } \\
\text { leadership }\end{array}$ & 0,663 & 0,305 \\
\hline & $\begin{array}{l}\text { Flexible } \\
\text { Structure }\end{array}$ & 0,473 & 0,215 \\
\hline
\end{tabular}

As one can see from table 2, transformational leadership has the highest impact on proactive behavior $(0,663)$; knowledge culture takes the second place and flexible structure the third one. All three mechanisms are significant and promote proactive patterns of employee behavior. Moreover, these mechanisms have indirect impact on innovation; it occurs through knowledge capability and confirms its mediation role in knowledgedriven innovation. Among three mechanisms, transformational leadership demonstrates the highest impact on innovation $(0,305)$.

The study reveals that organizational learning has the highest impact on innovation $(0,708)$, while the impact of knowledge resources is significant but weak $(0,140)$. This empirical fact confirms that knowledge resources are not the only one antecedent of company's innovation. For successful innovation the organizational learning should be activated with the help of proactive behavior, which in turn can be induced through knowledge culture, transformational leadership and flexible structure.

\section{Conclusions}

This study elaborated the novel theoretical framework for knowledge-driven innovation of a company. This model underlines the key role of proactive employee behavior for successful transformation of knowledge into company's innovations. Moreover, the model proposes three mechanisms, such as knowledge culture, transformational leadership and flexible structure, which might induce proactive behavior. The elaborated framework for knowledge-driven innovation can be used by other scholars for further research and, therefore, contributes to knowledge and innovation management field.

Using the sample of Russian companies, the paper confirmed the crucial role of knowledge management for innovation in Russian business-context. The empirical evidence of positive significant impact of organizational learning on innovation confirmed the first proposition of elaborated theoretical framework of knowledge-driven innovation. Further, significant indirect effects of proactive behavior on company's innovation proved the second theoretical proposition of the model. Last but not least empirical conclusion obtained in this study supports the third proposition about the knowledge-driven innovation chain, which starts with three mechanisms conditioning proactive behavior and its impact on knowledge resources and organizational learning.

The study has practical implications expressed in empirical evidence of complementarity of knowledge culture, transformational leadership and flexible structure. For company it means that three mechanisms should be implemented or improved simultaneously for better impact on proactive behavior. The highest impact of transformational leadership determines this particular mechanism as a crucial for Russian companies.

\section{Acknowlegements}

The study has several limitations. Namely, the empirical evidence is restricted with Russian companies and the sample was collected using snowball technique, which does not produce a representative sample. At the same time, the study is based on the solid literature and provides interesting insights about antecedents of innovation in Russian business context. This knowledge is novel and gives other scholars new directions for future research.

\section{References}

1. S.Roper, J. Du, J. H. Love, Res. Pol. 37, 6-7 (2008)

2. S.Cabrilo, ,S. Dahms, J. Know. Man. 22, 3 (2018)

3. L. Gohberg, K. Ditkovskij, E. Evnevich Science, Technology. Innovation (NRU HSE, Moscow, 2021)

4. A.Kianto, J. Sáenz, , N. J. Aramburu, Bus. Res. 81 (2017)

5. $\quad$ R. Grant, Strat. Man. J. 17 (1996)

6. C. Argyris, D.A. Schön, Organizational learning: a theory of action perspective (Addison-Wesley, Reading, MA, 1978)

7. T.A. Stewart, Intellectual Capital (BDD Publ. G., New York, NY, 1997)

8. A. Molodchik, S. Komarov, I. Esaulova, D. Dimitrakiev, Mechanisms and forms of selfdevelopment and self-organization (PNRPU, Perm, 2019)

9. Oslo Manual 2018, $4^{\text {th }}$ ed. Retrieved from: https://www.oecd.org/science/oslo-manual-20189789264304604-en.htm

10. D.A. Garvin, A.C. Edmondson, F. Gino, $H B R$. March (2008)

11. J.M. Crant J. Man. 26, 3 (2000)

12. S.K. Parker, Bindl U.K., K. Strauss, J. Man. 36, 4 (2010)

13. M.M. Pellegrini, F. Ciampi, G. Marzi, B. Orlando, J. Know. Man. 24, 6 (2020)

14. M. Mahmoudsalehi, M. K. Sahari Learn. Org. 19, 6 (2012)

15. T. Gavrilova, A. Alsufyev, A. Pleshkova, Meas. Bus. Exc. 22, 3 (2018) 
16. M. Molodchik, C. Jardon, Learn. Org. 22, 6 (2015)

17. C. M. Ringle, S. Wende, J.-M. Becker, 2015.

"SmartPLS 3." Boenningstedt: SmartPLS GmbH,

Retrieved from: http://www.smartpls.com 